\title{
Muzej Međimurja Čakovec i obitelj Zrinski: problemi i izazovi prezentacije raznesene materijalne baštine
}

Žvorc, Maja

Source / Izvornik: Institucije povijesti umjetnosti : zbornik 4. kongresa hrvatskih povjesničara umjetnosti, 2019, 73 - 79

Conference paper / Rad u zborniku

Publication status / Verzija rada: Published version / Objavljena verzija rada (izdavačev PDF)

https://doi.org/10.31664/z4khpu.09

Permanent link / Trajna poveznica: https://urn.nsk.hr/urn:nbn:hr:254:125867

Rights / Prava: Attribution 4.0 International/Imenovanje 4.0 međunarodna

Download date / Datum preuzimanja: 2023-04-26

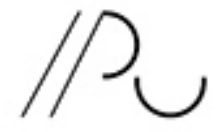

INSITIUT ZA POVIJEST UMJETNOSI
Repository / Repozitorij:

PODEST - Institute of Art History Repository

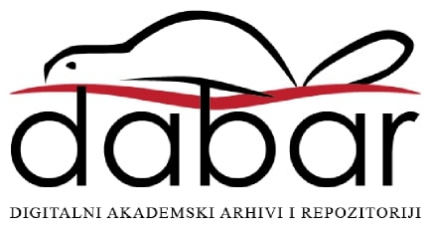




\section{Muzej Međimurja Čakovec i obitelj Zrinski: problemi i izazovi prezentacije raznesene materijalne baštine}

Čakovečki Stari grad novovjekovni je kompleks koji se sastoji od četverokrilne palače $s$ unutrašnjim dvorištem okružene fortifikacijskim sustavom zidina i bastiona (sl. I). U palači, u kojoj je danas smješten Muzej Međimurja, tijekom povijesti prebivalo je nekoliko plemićkih obitelji, od kojih je za međimursku, ali i hrvatsku povijest najvažnija obitelj Zrinski. Od I546. do I69I. Čakovec je bio sjedište pet naraštaja te velikaške

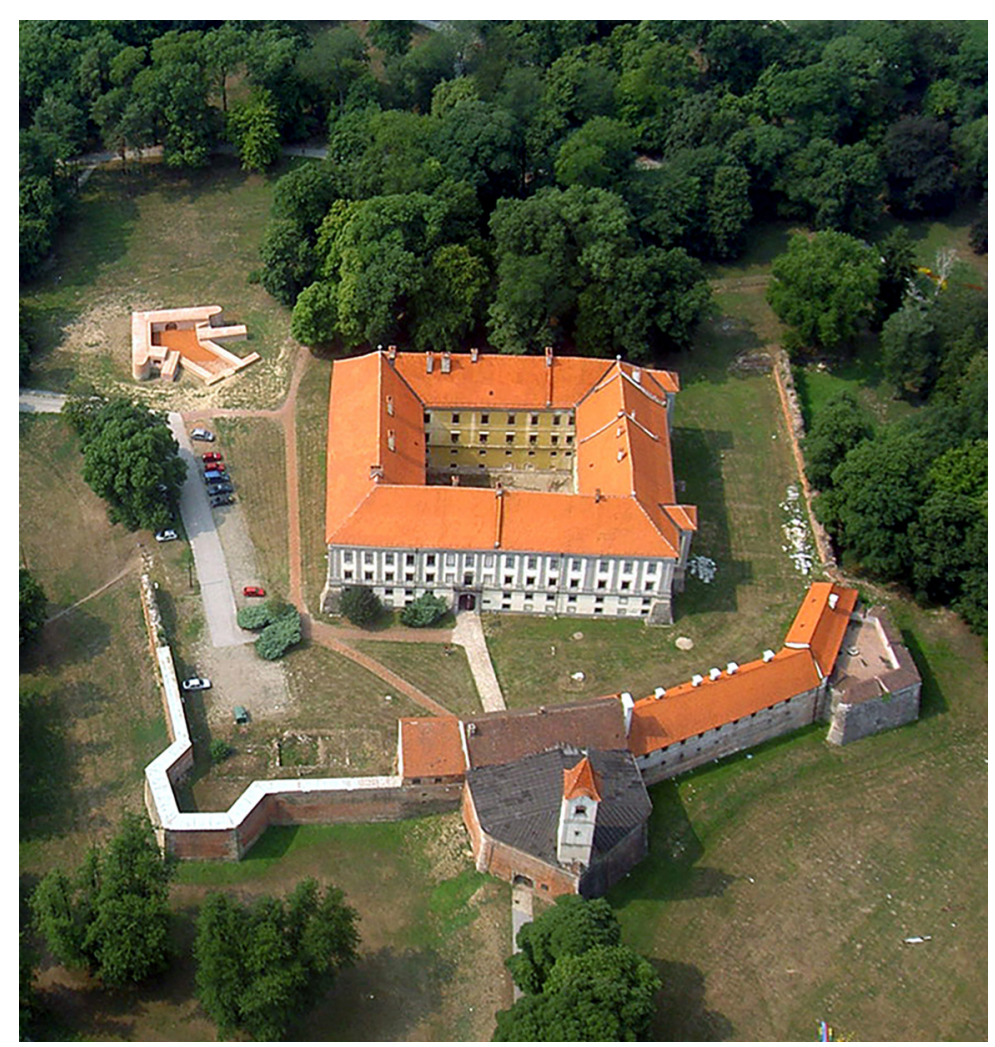

\section{Maja Žvorc}

samostalna istraživačica

zvorc.maja@gmail.com

(D) https://orcid.org/oooo-ooo2-2659-I22X
Slika I

Čakovečki Stari grad s palačom i okolnom

fortifikacijom

fototeka MMČ-a 


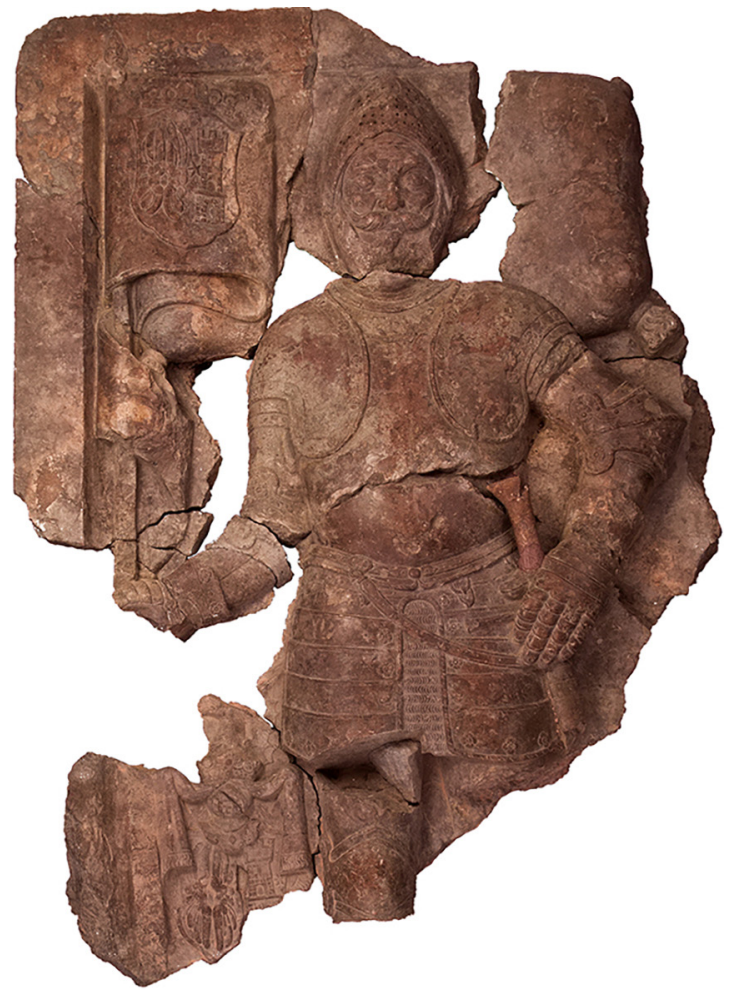

\section{Slika 2}

Nadgrobna ploča Nikole IV. Zrinskoga (†

mramor, $\mathrm{I} 62 \times \mathrm{II}_{5} \times 22,5 \mathrm{~cm}$, Čakovec, Muzej Međimurja Čakovec, inv. br. MMČ II 564 , fototeka MMČ-a

\section{Slika 3}

Povelja Jurja IV. Zrinskoga, I579.

pergamena, vosak, $25 \times 75 \mathrm{~cm}$,

Čakovec, Muzej Međimurja

Čakovec, inv. br. MMČ II 565 fototeka MMČ-a

\section{Slika 4}

Žlica s grbom obitelji Zrinski druga polovina I6. stoljeća, srebro, Čakovec, Muzej Međimurja Čakovec, inv. br. MMČ 27499 , fototeka MMČ-a

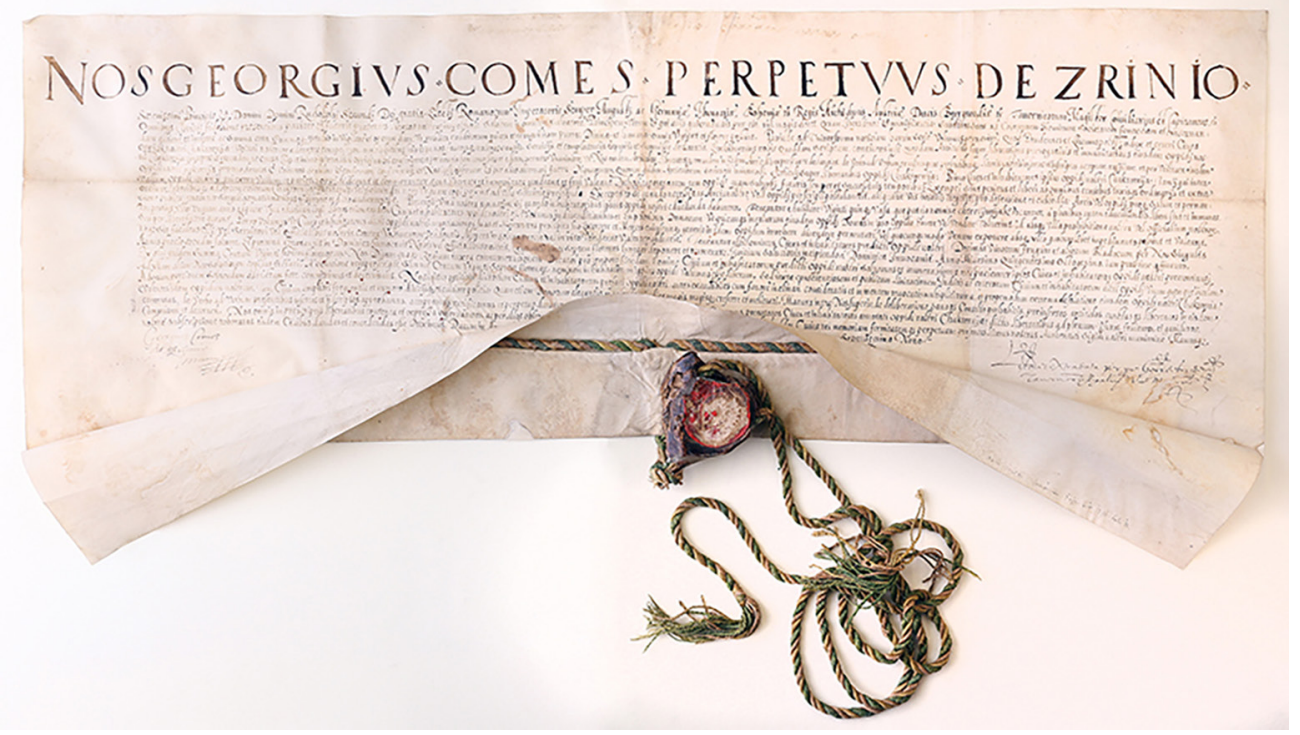


obitelji. Riječ je o naraštajima Nikole IV. (Zrin, oko I5o8.-Siget, I566.), poznatoga kao hrvatski Leonida, koji je pao pod opsadom Sigeta; Jurja IV. (Čakovec, I549.-Vép, I6o3.) koji je prvi otvoreno prigrlio protestantsku vjeru; Jurja v. (Čakovec, I599.-Bratislava, I626.) koji je vojevao u Tridesetogodišnjem ratu; braće Nikole VII. (Čakovec, I620.-Kuršanečki lug, I664.) i Petra IV. (Vrbovec, I62I. - Bečko Novo Mjesto, I67I.), u čije je vrijeme obitelj doživjela politički, gospodarski i kulturni vrhunac te Adama (Beč, I662.-Slankamen, I69i.), posljednjega člana obitelji koji je stanovao u Čakovcu. ${ }^{1}$

Tijekom druge polovine ı6. i prve polovine I7. stoljeća imanja obitelji Zrinski prostirala su se od rijeke Mure do sjevernoga Jadrana u kontinuitetu, usporedno s granicom Hrvatsko-Ugarskog Kraljevstva i Otomanskog Carstva, a čakovečko vlastelinstvo bilo je njihov najveći i najvažniji posjed. ${ }^{2}$ Zasad je poznato nekoliko suvremenih opisa čakovečkoga Staroga grada, ${ }^{3}$ a onaj najiscrpniji donio je u obliku putopisne bilješke nizozemski istraživač i filolog Jakob Tollius (Rhenen, I633.-Utrecht, I696.), koji je posjetio Čakovec r66o. godine, kada je ondje sa svojom obitelji stanovao Nikola VII. Zrinski. ${ }^{4}$ Tollius je opisao palaču kao „sjajan i prostran [dvorac], izvrsno utvrđen protiv turske sile", opremljen bogatim pokućstvom, knjižnicom, riznicom i oružarnicom, s trijemovima ukrašenima ratnim plijenom poput osmanskih zastava, štitova, lukova, strijela i sablji. ${ }^{5}$ Posebno je istaknuo zbirku slika koje su prikazivale Nikoline pothvate protiv Osmanlija, grofovu zbirku kovanica i medalja te uređeni vrt koji ga je sjajem i skladom podsjetio na vrtove feačkoga kralja Alkinoja. Tolliusov opis svjedoči o raskoši i visokoj kulturi življenja na dvoru Zrinskih u Čakovcu, unatoč činjenici što je njihova svakodnevica bila obilježena neposrednom blizinom i borbom protiv osmanskih snaga.

Značenje i duhovna ostavština obitelji Zrinski, koja je iznjedrila naraštaje vojskovođa, političara, gospodarstvenika i književnika neupitni su, no postavlja se pitanje u kojoj je mjeri očuvana njihova materijalna baština. U Muzeju Međimurja Čakovec, čiji fundus broji više od 27.0oo predmeta, pohranjeno je svega nekoliko predmeta neposredno povezanih sa Zrinskima. ${ }^{6}$ Riječ je o nadgrobnoj ploči (najvjerojatnije) Nikole IV. Zrinskog Sigetskog (sl. 2), koja se izvorno nalazila u obiteljskoj grobnoj kapeli prigrađenoj pavlinskoj samostanskoj crkvi u Šenkovcu, nedaleko Čakovca; desetak arhivskih dokumenata, od kojih je najvažnija povelja Jurja IV. Zrinskog iz I579. godine kojom je grof dodijelio stanovnicima podgrađa čakovečke tvrđave pravo trgovanja (sl. 3); te srebrna žlica s grbom obitelji Zrinski (sl. 4) koja je pronađena 20I5. godine arheološkim istraživanjem na lokaciji obrambenoga jarka sjeveroistočnoga dijela utvrde Staroga grada. Muzej čuva i manji broj uporabnih predmeta s kraja I6. i početka I7. stoljeća, poput dijelova oklopa, mačeva, mužara, lokota, ključeva i slično, no s obzirom na to da za veći dio predmeta u staroj knjizi ulaska i inventarnim knjigama pojedinačnih odjela ne postoje podaci o njihovoj provenijenciji ili načinu prikupljanja, teško je ustvrditi jesu li ti predmeti korišteni baš u čakovečkom Starom gradu.

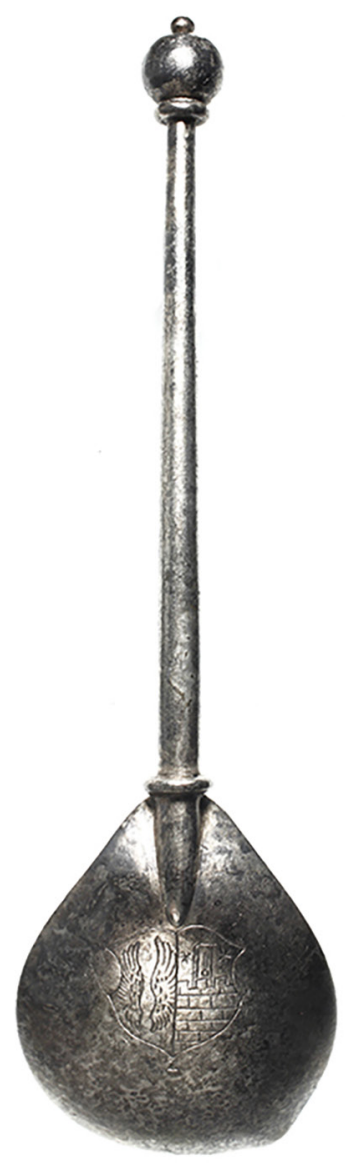

I VLADIMIR KALŠAN, Međimurska povijest, Čakovec, 2006., 57-I33.

2 JOSIP ADAMČEK, Zrinsko-frankopanski posjedi u XVII. stoljeću, u: Radovi Instituta za hrvatsku povijest Sveučilišta u Zagrebu, 2 (I972.), 23-46, 23, 25; NATAŠA ŠTEFANEC, Braća Nikola i Petar Zrinski. Velikaška obitelj u srednjoeuropskim vojno-političko-ekonomskim konstelacijama, u: Zrinski i Europa, (ur.) Jadranka Damjanov, Zagreb, 200o., 387-40I, 388.

3 Riječ je o opisu palače nastalu 1638 . godine $u$ povodu podjele imanja između Nikole viI. i Petra IV. te o opisima osmanskoga putopisca Evlije Čelebije (I66o.) i Sigismunda Trauttmansdorfa (I688.).

4 JACOBUs TOLliUs, Epistolae itinerariae: ex Auctoris Schedis Postumis Recensitae, Suppletae Digestae; Annotationibus, Observationibus \& Figuris adornatae, cura et studio Henrici Christiani Henninii, Amstelaedami, I70o., 237-246. Prijevod pisma nalazi se u: JACOBUS TOLLIUS, Šesto putno pismo Jakova Tolla. Preplemenitome i presvetlome gospodinu Nikoli Witsenu. Gradačko putovanje i gostoprimstvo Zrinskih, u: Zrinski i Europa, (ur.) Jadranka Damjanov, Zagreb, 2000., I5I-I58.

5 JACOBUS TOLLIUS (bilj. 4, I700.), 240-24I; JACOBUS TOLLIUS (bilj. 4, 2000.), I54-I55.

6 Zahvaljujem kustosicama Kulturno-povijesnog, Povijesnog i Arheološkog odjela Muzeja Međimurja Čakovec Maši Hrustek Sobočan, Branki Marciuš i Ani Šestak, na njihovoj srdačnosti i pomoći koju su mi pružile tijekom ovog istraživanja. 
U kupoprodajnom ugovoru sklopljenu i933. godine između trgovačkog društva Slavonija d.d., tadašnjega vlasnika Staroga grada, koji ga je zbog lošega stanja uzrokovana desetljećima neodržavanja planirao srušiti, ${ }^{7}$ i Obrtnoga zbora za trgovište i kotar Čakovec, koji je kupnjom spasio kompleks od uništenja, popisana je sva pokretna imovina koja se tada nalazila u palači. ${ }^{8}$ Popisan je inventar dvorske kapele svetoga Franje Ksaverskoga koja se nalazila na mezaninu sjeveroistočnoga krila, nekoliko zemljanih peći i toranjskih zvona, štafelajna slika alegorijskog sadržaja s kraja I8. stoljeća koja je danas pohranjena i izložena u Muzeju te zbirka dvadesetak kamenih portretnih poprsja hrvatskih i ugarskih dostojanstvenika-među njima i onih Nikole VII., Petra IV. i Adama Zrinskoga (sl. 5)-danas izložena u muzejskom lapidariju, za koju još nije sa sigurnošću utvrđeno je li nastala sredinom i7. ili u prvoj polovini Ig. stoljeća.

S obzirom na mali broj sačuvanih predmeta koji svjedoče o kulturi življenja obitelji Zrinski na čakovečkom dvoru, nameće se pitanje koji je razlog malobrojnosti očuvane građe. Izuzev uobičajenoga procesa raznošenja predmeta od strane kasnijih vlasnika Staroga grada, glavni uzrok tome je Zrinsko-frankopanska urota. Nezadovoljni apsolutističkom i centralističkom politikom bečkoga dvora, hrvatski i ugarski velikaši organizirali su se $u$ protuhabsburški ustanak s namjerom zbacivanja Habsburgovaca s hrvatsko-ugarskoga prijestolja. ${ }^{9}$ Ustankom u Hrvatskoj u početku je rukovodio Nikola VII. Zrinski, no nakon njegove tragične pogibije I664. godine, njegov mlađi brat Petar IV. doselio je iz Ozlja u Čakovec i preuzeo bratovo mjesto. Saznavši za urotu, car Leopold I. dao je i67o. godine uhititi njezine glavne predvodnike-među njima Petra IV. Zrinskoga i njegova šurjaka Frana Krstu II. Frankopana-optužio ih i osudio za veleizdaju te naposljetku dao javno pogubiti.

Nakon što su urotnici uhićeni, Ugarska dvorska komora izdala je ispravu kojom su konfiscirana sva imanja Petra IV. Zrinskoga i njegovih suučesnika, a na njihove posjede poslani su carski službenici s glavnom zadaćom popisivanja i procjene pokretnih i nepokretnih dobara. ${ }^{10} \mathrm{U}$ domaćoj historiografiji zasad su objavljena i znanstveno obrađena četiri takva popisa, koja daju uvid u bogatstvo i količinu predmeta koji su se nalazili na čakovečkom dvoru, ${ }^{11}$ premda ni oni ne pružaju potpunu sliku jer su prije dolaska službenika pripadnici carske vojske, koju je Leopold I. poslao u Međimurje kao mjeru opreza, opljačkali palaču i odnijeli različite vrijednosti. ${ }^{12}$ Prema popisima, na čakovečkom dvoru nalazile su se mnogobrojne dragocjenosti: čisto zlato i srebro; skupocjeni nakit; slike i skulpture; hladno
Joso (?), Hoće li grad Zrinskih u Čakovcu biti sravnjen sa zemljom, u: Novosti, I8. studenoga I932., 7 .

8 MAŠA HRUSTEK SOBOČAN, 6o godina Muzeja Međimurja Čakovec, Čakovec, 20I4., II. Ugovor je pohranjen u Povijesnom odjelu Muzeja (inv. br. II538).

9 VLADIMIR KALŠAN (bilj. I), II7-I28; ANĐELKO MIJATOVIĆ, Zrinsko-frankopanska urota, Zagreb, I992., 64-99.

IO VLADIMIR KALŠAN (bilj. I), I29; RAJKA MODRIĆ, Monumenta historica familiarum Zrinski et Frankopan, vol I. Conscriptiones et aestimationes bonorum (1672-ı673), Zagreb, I974., [i].

II Broj popisa koji se odnose na ostale posjede Zrinskih i Frankopana znatno je veći. Popise predmeta odnesenih s čakovečkog imanja prvi su objavili: IVAN KUKULJEVIĆ SAKCINSKI, Dragocene i umetne stvari grofovah Zrinjskih u gradu Čakovcu, u: Arkiv za povjesticu jugoslavensku, I (I85I.), I55-I73 (objavljena dva popisa nastala u Čakovcu, 3o. X. I67ı. i Krapini, 2. VI. I68I.); FRANJO RAČKI, Izprave o uroti bana P. Zrinskoga i kneza Fr. Frankopana, Zagreb, I873., 556-586; RAJKA MODRIĆ (bilj. Io), I-I8.

I2 VLADIMIR KALŠAN (bilj. I), I25-I26.

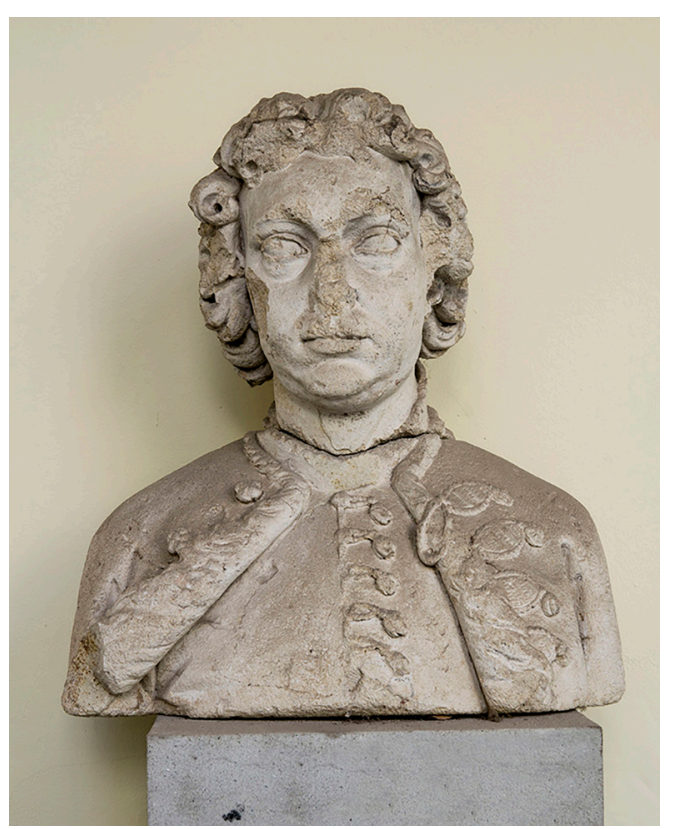




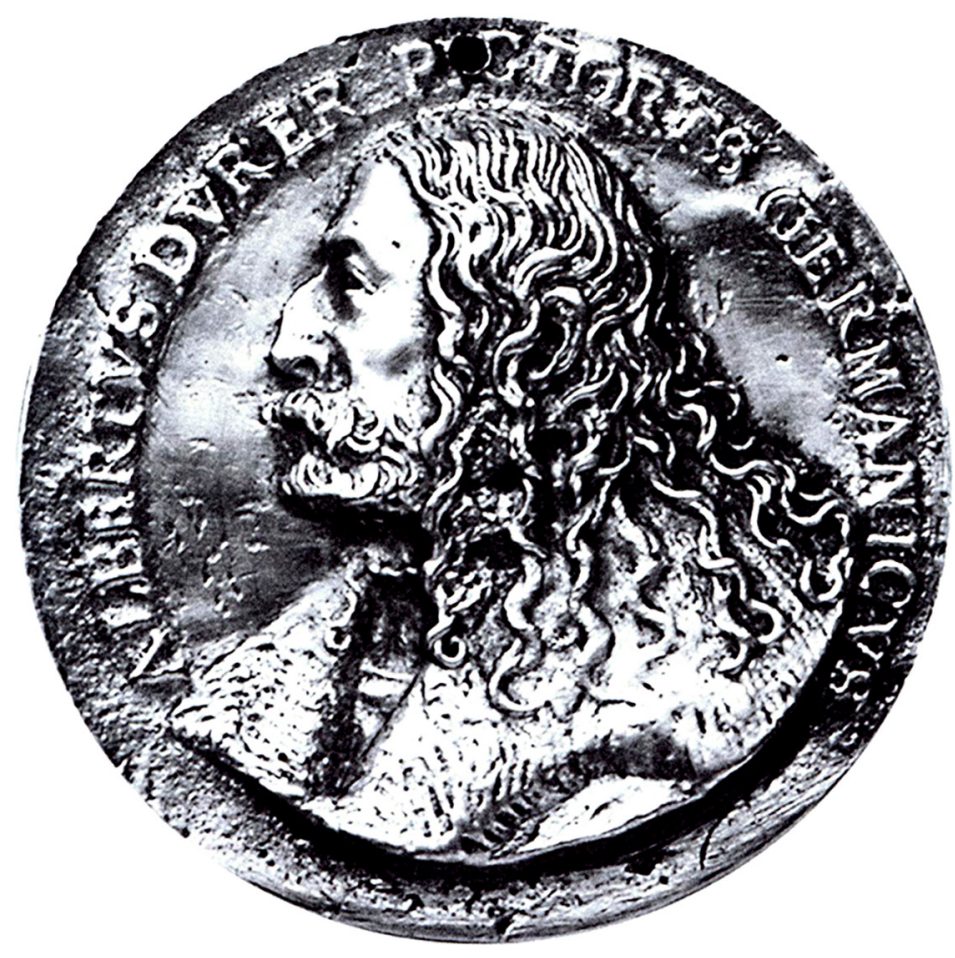

i vatreno oružje; konjska oprema; odjeća izrađena od baršuna, atlasa, svile i brokatnog zlata; bale raznovrsnih skupocjenih tkanina; pokrivači, sagovi i tepisi; stakleno i metalno posuđe; ormari, stolice, satovi, škrinje, kreveti i drugo pokućstvo.

$\mathrm{Na}$ osnovi navedenih popisa pokretnih dobara, opisa čakovečke palače Jakoba Tolliusa i drugih arhivskih dokumenata, Žarka Vujić u svojim je istraživanjima pokušala rekonstruirati dio baštinskoga fonda koji se nalazio na dvoru Nikole VII. ${ }^{13}$ Uspoređujući izvore s katalozima hrvatskih i inozemnih muzeja, ušla je u trag desetak predmeta koji su se izvorno najvjerojatnije nalazili u Čakovcu. Riječ je o srebrnom vrču u obliku Cerere, dvjema kutijama ukrašenima dragim kamenjem, kaležu u obliku školjke, skulpturi Alegorije smrti, vrču u obliku jelena i medalji s likom Albrechta Dürera (sl. 6) (svi predmeti danas su pohranjeni u Mađarskom narodnom muzeju u Budimpešti), potom o držaču za barut koji je najvjerojatnije pripadao Nikoli IV. Zrinskom (danas u Balatoni Múzeumu u Keszthélyu) te o pištolju na kolo s imenom obitelji Zrinski i velikom globusu (pohranjeni u Hrvatskom povijesnom muzeju u Zagrebu). ${ }^{14}$

Veliko značenje za kulturnu baštinu obitelji Zrinski ima i osobna knjižnica Nikole VII., koju je u svom opisu spomenuo i Jakob Tollius. ${ }^{15}$ Srećom, knjižnica je izbjegla sudbinu drugih obiteljskih vrijednosti u vrijeme konfiskacija i ostala je na čakovečkome dvoru do smrti Nikolina sina Adama, koji ju je dopunjavao vlastitim knjigama i rukopisima. ${ }^{16}$ Nakon Adamove smrti njegova supruga Marija Katarina rođena Lamberg preudala se

\section{Slika 6}

Medalja s likom Albrechta

Dürera, nakon I520.

srebro, Budimpešta,

Magyar Nemzeti Múzeum,

fotografija preuzeta iz:

Žarka Vujić, Izvori muzeja u

Hrvatskoj, 2007.
I3 ŽARKA vUJIĆ, Baštinski svijet Nikole Zrinskoga u Čakovcu, u:Zrinski i Europa, (ur.) Jadranka Damjanov, Zagreb, 200o., I2 - 45; ŽARKA VUJIĆ, Europskim putovima razasute baštine Nikole Zrinskoga, u: Zrinski i Europa 2, (ur.) Jadranka Damjanov, Zagreb, 2003., 20-47; ŽARKA vUJIĆ, Izvori muzeja u Hrvatskoj, Zagreb, 2007.

I4 ŽARKA VUJIĆ (bilj. I3, 2000.), 23, 28, 35; ŽARKA VUJIĆ (bilj. I3, 2003.), 2I, 24-27; ŽARKA VUJIĆ (bilj. I3, 2007.), 92, IIO, I75-I76.

I5 JACOBUS TOLliUS (bilj. 4, I700.), 24I; JACOBUS TOLLIUS (bilj. 4, 2000.), I54.

I6 GÁBOR HAUSNER, ISTVÁN MONOK, GÉZA ORLOVSZKY, A Bibliotheca Zriniana története, $\mathrm{u}$ : A Bibliotheca Zriniana története és állománya $=$ History and Stock of the Bibliotheca Zriniana, (ur.) Gábor Hausner et al., Budapest, I99I., 2I-82, 57, 60; IVAN KOSIĆ, Bibliotheca Zriniana, u: Plava krv, crna tinta: knjižnice velikaških obitelji od I500. do I70o. Međunarodna putujuća izložba:Zagreb, Bratislava, Martin, Budapest, Forchtenstein, jesen 2005.-jesen 2007., (ur.) Ivan Kosić, Zagreb, 2005., I7-24, 21 . 
za moravskoga plemića Maxmiliána Arnošta II. Jankovskog z Vlašimi i odnijela knjižnicu sa sobom u dvorac pored sela Bítova (njem. Vöttau), u kojem je stanovala sa svojim novim suprugom. Baštinici obitelji Vlašim, obitelj Draun, prodali su knjižnicu I89o. godine bečkome antikvaru Samuelu Kendeu, koji ju je dvije godine poslije prodao za I2.ooo forinti hrvatskoj vladi. ${ }^{17}$ Bibliotheca Zriniana tako je danas pohranjena u zagrebačkoj Nacionalnoj i sveučilišnoj knjižnici, a sadržava 500 svezaka knjiga i 29 rukopisa (pretpostavlja se da je u vrijeme Adama Zrinskoga sadržavala više od 8 oo naslova). ${ }^{18}$ U usporedbi s knjižnicama Nikolinih suvremenika, poput one biskupa Aleksandra Ignacija Mikulića, Adama Batthyányja, Ferenca Nádasdyja ili Istvána Csákyja, čakovečka knjižnica brojem svezaka nije nadilazila ondašnji prosjek, no ono čime se isticala bila je njezina klasifikacija ${ }^{19}$ te suvremenost i raznolikost naslova koje je sadržavala. ${ }^{20}$

Osnovni muzeološki problem koji se ovdje postavlja jest pitanje načina prezentacije kulture i življenja obitelji Zrinski na čakovečkom dvoru s obzirom na to da je većina predmeta koji imaju funkciju materijalnoga svjedočanstva raznesena. Mogućnost povrata građe čini se prilično neizglednom jer su pregovori o restituciji hrvatskih dobara koja su se nalazila na području Mađarske okončani I958. godine sklapanjem sporazuma između FNR Jugoslavije i NR Mađarske. Restitucijom je vraćen velik dio arhivskoga gradiva koji je raznesen s obiteljskih imanja, no od muzejskih predmeta vraćena je samo nadgrobna ploča Nikole IV. Zrinskoga, koja se dotad nalazila u budimpeštanskom Muzeju likovnih umjetnosti. ${ }^{21}$ Iako su istraživanjima Žarke Vujić identificirani predmeti koji su nekoć bili dio kulturne baštine obitelji Zrinski, problem leži u nedostatku potrebne dokumentacije koja bi nepobitno dokazala da je uistinu riječ o predmetima koji su se izvorno nalazili u Čakovcu.22 Dodatno, institucije koje posjeduju željena kulturna dobra često koriste argument zakonitosti, da su željeni predmeti „stečeni na način zakonit u vrijeme njihove akvizicije i da [tako] potpadaju pod jurisdikciju zemlje u kojoj se nalaze" te da se „već tako dugo vremena nalaze u [toj] zemlji da se mogu smatrati dijelom [njezina] kulturnog nasljeđa". ${ }^{23}$ Mogućnost otkupa ponovno ovisi o voljnosti institucije u kojoj se nalaze potraživana dobra da ih proda, jednako kao i o financijskim mogućnostima ustanove koja traži povrat predmeta da ih otkupi. Kao alternativa nameće se izrada trodimenzionalnih kopija izvornih predmeta ili pak njihova virtualna rekonstrukcija i prezentacija s pomoću suvremenih informacijskih tehnologija.

Primjer posljednjeg rješenja virtualna je rekonstrukcija knjižnice Nikole VII. Zrinskoga nastala u sklopu projekta Bibliotheca Eruditionis (200I.-2002.) koji su provele Nacionalna knjižnica Széchényi i Sveučilišna knjižnica u Segedinu s osnovnim ciljem izrade bibliografije knjiga izdanih na području panonske nizine u i6. i i7. stoljeću. ${ }^{24}$ Izradi rekonstrukcije Nikoline knjižnice u Čakovcu prethodilo je izdavanje opsežnoga kataloga A Bibliotheca Zriniana története és állománya (I99i.), koji je izradila skupina mađarskih znanstvenika, ${ }^{25}$ a izgled Nikoline
I7 GÁBOR HAUSNER, ISTVÁN MONOK, GEZA ORLOVSZKY (bilj. I6), 78-79; IVAN KOSIĆ (bilj. I6), I7, 22.

I8 GÁBOR HAUSNER, ISTVÁN MONOK, GÉZA ORLOVSZKY (bilj. I6), 68; IVAN KOsı́́ (bilj. I6), 2I.

I9 Prema rukopisnome katalogu koji je Nikola VII. Zrinski dao načiniti I662. godine (CATALOGUS OMNIUM LIBRORUM BIBLIOTECAE [sic] CHAKTORNIENSIS EXCELL[ENTISSI]MI ATQUE IL[LUSTRISSI] MI D[OMI]NI COMITIS NICOLAI A ZRINIO BANI. ANNO DOMINI 1662 DIE 10 OCTOBRIS), svesci su bili podijeljeni na jedanaest cjelina. Katalog je također pohranjen u Nacionalnoj i sveučilišnoj knjižnici u Zagrebu, u Zbirci rukopisa i starih knjiga (sign. R 3579).

20 GÁBOR HAUSNER, ISTVÁN MONOK, GÉZA ORLOVSZKY (bilj. I6), 50-5I; ŽARKA vUJIĆ (bilj. I3, 200o.), 34.

2I MARIJANA SCHNEIDER, Jedan se spomenik vratio kući..., u: Vijesti Društva muzejsko-konzervatorskih radnika NR Hrvatske, 7/4 (I958.), Io8-IIo, II0. Arhivska građa većim je dijelom pohranjena u Hrvatskom državnom arhivu u Zagrebu.

22 Prema Zakonu o zaštiti i očuvanju kulturnih dobara (Čl. 70.a-f) i Zakonu o potvrđivanju UNIDROIT-ove konvencije o ukradenim ili nezakonito izvezenim kulturnim dobrima, institucija koja traži povrat građe obvezna je uz zahtjev priložiti detaljnu dokumentaciju o potraživanom predmetu.

23 ANDROMACHE GAZI, Muzeji i nacionalno kulturno blago, u: Informatica museologica, 23/I-4 (I993.), I7 $-23,22$.

24 Bibliotheca Eruditionis: the Programme, http://www. eruditio.hu/programeng.html (posjećeno I5. studenoga 20I6.).

25 Vidi bilješku 16. 
knjižnice rekonstruiran je na osnovi povijesnih izvora (rukopisnoga kataloga knjižnice iz i66o. godine, oporuci Nikole VII. i navedenih popisa konfisciranih dobara) te očuvanih suvremenih primjeraka komada pokućstva i njihovih likovnih prikaza. ${ }^{26}$

Još je jedan komparativni primjer nekadašnja bogata zbirka obitelji Gonzaga, koja je svojevremeno sadržavala oko 20.000 predmeta, uključujući oko 2.000 štafelajnih slika, brončane i mramorne skulpture, medalje, kovanice, keramiku, rukopise, knjige i druge vrijednosne predmete. ${ }^{27}$ Zbirka je nastala sabiračkim djelovanjem šest naraštaja obitelji Gonzaga od početka I6. do tridesetih godina I7. stoljeća, a sadržavala je djela poznatih europskih majstora poput Andree Mantegne, Tiziana, Correggia, Domenica Tintoretta, Pietera Pauwela Rubensa i drugih. Rasipanje zbirke započelo je smrću vojvode Ferdinanda Gonzage (Mantova, I587.- I626.), čiji su potomci najbolja ostvarenja štafelajnoga slikarstva u zbirci prodali između I627. i ı63o. godine engleskome kralju Charlesu I. (vl. ı625.- - 649.), a ostatak je raznesen ili uništen u Ratu za mantovansko nasljeđe (I627.- I63I.). ${ }^{28}$ Kao rezultat petogodišnjeg istraživanja skupine stručnjaka, potkraj 2002. godine u Palazzo Te otvorena je izložba Gonzaga: La Celeste Galeria, kojom je javnosti predstavljeno devedesetak slika i dvjestotinjak drugih predmeta posuđenih iz muzeja i galerija diljem svijeta koji su nekoć pripadali zbirci obitelji Gonzaga. ${ }^{29}$ Iako je na taj način prezentiran dio nekoć bogate mantovanske baštine, on predstavlja vremenski ograničeno rješenje s obzirom na to da su nakon zatvaranja izložbe umjetnine vraćene njihovim institucijama.

Od 20og. godine palača čakovečkoga Staroga grada postupno se statički sanira. ${ }^{30}$ Sanacija je uzrokovala privremene izmjene i prilagodbe stalnoga postava, no po njezinu završetku stručno osoblje Muzeja Međimurja u Čakovcu planira predstaviti novi zajednički stalni postav Arheološkog, Povijesnog i Kulturno-povijesnog odjela, od kojih svaki dijelom obuhvaća dio povijesti obitelji Zrinski. U novome postavu materijalna i duhovna baština obitelji Zrinski bit će prezentirane ustaljenim metodama-s pomoću samih izložaka te tekstualnih i slikovnih priloga-ali i uz pomoć suvremenih informacijskih tehnologija, odnosno virtualnom rekonstrukcijom čakovečkoga dvora i njegova fundusa u vrijeme Zrinskih. Na taj način posjetiteljima će se pokušati dočarati političko, gospodarsko, društveno i kulturno značenje koje je obitelj Zrinski imala za povijest hrvatskoga ranog novog vijeka.
26

Bibliotheca Zriniana 3D: How was it made?, http:// www.eruditio.hu/zrinyizd/how/index.html (posjećeno I2. rujna 20I6.).

27 RODERICK CONWAY MORRIS, A gathering of Renaissance masters, u: The New York Times, objavljeno 23 studenoga 2002., http:/www.nytimes.com/2002/II/ 23/style/a-gathering-of-renaissance-masters.html (posjećeno I2. studenoga 20I6.).

28 CHRISTINA M. ANDERSON, The art of friendship: Daniel Nijs, Isaac Wake and the sale of the Gonzaga collection, u: Renaissance Studies, XXVII/5 (2013.), 724-737, 724.

29 LUCA SCALCO, Gonzaga - la Celeste Galeria. Mantova, Palazzo Ducale-Palazzo Te, objavljeno 2. rujna 2002. http://www.exibart.com/notizia.asp?idnotizia=5340 (posjećeno I5. studenoga 2oi6.).

3O MAŠA HRUSTEK SOBOČAN (bilj. 8), 67.

\section{(ㅇ) (1)}

Muzej Međimurja Čakovec i obitelj Zrinski: problemi i izazovi prezentacije raznesene materijalne baštine / Maja Žvorc/ CC BY / 4.0

DOI: https://doi.org/ıo.3I664/z4khpu.o9 